\title{
Full scale vermicomposting and land utilisation of pulpmill solids in combination with municipal biosolids (sewage sludge)
}

\author{
M. Quintern \\ Quintern Innovation Ltd. \& Noke Limited, New Zealand
}

\begin{abstract}
More than 180,000 tonnes of carbon rich fibrous by-products from New Zealand's largest pulp and paper mills have been disposed to landfills for decades. The aim of this project was to identify a sustainable source of nutrient as well as a cost effective technology to produce a high quality soil conditioner or fertiliser. Blending pulpmill solids with nutrient rich municipal biosolids (sewage sludge) was considered highly suitable for vermicomposting. The project, which commenced in 2007, proved the efficacy of the sludge through both laboratory and field trials. The design of a full industrial scale vermicomposting process had been developed and evaluated at a pilot scale of 2,000 tonnes blended wastes. We are operating as a full scale commercial business processing 150,000 tonnes of organic waste per year via compost worms. Through this we have supported two pulp and paper mills to attain organic waste free status. Furthermore biosolids from three communities with a total of 220,000 people are processed on 50 hectares of vermicomposting worm farms. The target for 2015 is that the remaining pulp mill will also attain an organic waste free status along with further communities comprising of some 120,000 people sending their biosolids to the vermicomposting operations taking the total product to some 230,000 tonnes per year. More than 20,000 tonnes of high quality vermicast is currently produced, which complies with the qualification criteria of an AA-grade product, as determined by the New Zealand biosolids guideline. The final vermicast is applied to more than 1,000 ha of farmland, orchards, nurseries and golf courses with growing demand.

Keywords: vermicomposting, vermicast, pulpmill solids, biosolids, sewage sludge, land utilisation.
\end{abstract}




\section{Introduction}

In New Zealand 5 pulp and paper mills plus 2 recycled paper mills are producing 203,000 tonnes of organic wastes [1]. The main organic by-products of the pulp and paper mills are primary pulpmill solids separated at the first stage of the wastewater treatment plant usually through a clarifier. Applying polymers and screening the solids fractions are separated from the effluent and with further technical dewatering results in a product which is has an approximate 20 to $25 \%$ solids composition. In some alternative processes, clarifier sediments are pumped into dewatering ponds where the sludge is dewatering slowly by draining of excess water back into the wastewater treatment plant. This type of sludge contains some 15 to $20 \%$ solids content. These primary solids are generally high in carbon and low in plant valuable nutrients. If primary solids are applied to farmland, nitrogen and phosphate fertiliser application have to be increased to avoid nutrient immobilisation [2]. Land application to New Zealand forest has been trialed at small scale with little success [3] thought the relatively young volcanic soils as are typical in New Zealand are low in organic matter and would benefit from organic soil conditioners. There are instances of small scale direct application of pulp and paper solids having been applied to land under controlled conditions to assess the potential risks on soil and water ecosystems [4].

Until now the primary solids originating from the pulp and paper mills have either been disposed of in landfills and where no landfill capacity is available have been combusted for electricity production but with negative energy gain due to the high water content and which still requires the boiler ash to be disposed of to landfill.

Biological sludge from oxidation ponds, also known as secondary pulpmill solids, has slightly higher nitrogen and phosphate concentration and a lower carbon concentration. This narrower $\mathrm{C} / \mathrm{N}$ ratio makes secondary pulpmill solids more suitable for land utilisation [3].

Sewage sludge is defined in New Zealand as municipal biosolids [5]. The guidelines for the safe application of biosolids to land in New Zealand [5] require stabilisation treatment to reduce pathogens and testing on contamination to achieve an AA-grade classification prior to unrestricted land application. Most of the produced municipal biosolids would not meet the a-grade contamination classification and would require a blending agent for diluting heavy metal concentrations. Stabilisation such as drying, composting and liming (high $\mathrm{pH}$ ) are cost intensive resulting in most of the biosolids produced in New Zealand being land filled.

Vermicomposting of purely pulpmill solids has not been conducted at any significant scale, as the wide $\mathrm{C} / \mathrm{N}$ ratio of pulpmill solids is not suitable for vermicomposting. Laboratory trials have shown best reproduction of earthworms when the $\mathrm{C} / \mathrm{N}$ ratio is adjusted at about 25 with nitrogen richer waste streams [6-8]. Various industrial organic wastes have been studied for four decades using vermicomposting technology to produce a high quality soil conditioner or fertiliser [9]. Paper wastes with a $\mathrm{C} / \mathrm{N}$ ratio of up to 200 and higher, were used as 
a carbon rich blending agent for nutrient rich wastes such as biosolids, food wastes [10], manure [11], and other industrial wastes [12]. Since the 1990th solids from pulp and paper mills were used as carbon rich fibre for blending with nutrient rich wastes in vermicomposting processes $[6,12-16]$. In recent years Quintern and his team $[17,18]$ have been demonstrating that a sub-optimal C/N ratio in the earthworm feedstock can be successful in commercial vermicomposting operations and nitrogen sources captured from the wastewater treatment plant of a pulpmill can be used as nitrogen source for blending with primary pulpmill solids [19].

\section{Materials and methods}

The characteristics of pulpmill solids tend to vary considerably. Variations are also found between different pulp mills, as well as between different types of solids originating from individual pulp mills. In addition, further variations are also noted as the age of the solids increases. This paper focuses on Quintern's work at two pulp and paper mills, which have identified inconsistencies within their waste solids.

Our operation at the Kinleith pulp and paper mill at Tokoroa in New Zealand's North Island is mainly vermicomposting a mix of primary and secondary solids producing an organically certified Vermicompost. A part of the operation operates on leased land contained within an organically certified dairy farm and which requires all inputs onto the worm farm to be a certified organic input for vermicomposting on an organic certified worm farm. Table 1 shows the characteristics of the pulpmill solids originating from the Kinleith pulp and paper mill compared to the specified limits for organic certification [20].

At the Tasman pulp and paper mill situated at Kawerau in the Bay of Plenty region of New Zealand North Island, the Vermicompost we produce comprises primary pulpmill solids in combination with municipal biosolids from Rotorua city. Characteristics of both sludges are shown in Table 2 and compared against the limits for the safe application of biosolids to land in New Zealand [5].

\section{Industrial vermicomposting operations in New Zealand}

The journey of establishing two industrial scale vermicomposting operations at the largest pulp and paper mills in New Zealand started in 2007 with laboratory batch trials to combine industrial produced organic wastes streams produced in the region on their suitability for vermicomposting. The favourable initial results quickly led to large-scale field trials intended to evaluate the vermicomposting process under real climatic conditions. These trials were crucial to establishing proof of concept and to establish the operational costs and wider economic benefit data as well as demonstrating environmental impacts to regional environmental authorities and similar organisations responsible for the granting of operational resource consents. A significant consideration throughout these trails was to engage closely with the indigenous tribes (iwi) for social and 
Table 1: $\quad$ Characteristics of primary, secondary, and recycled paper solids from Kinleith Pulp, Paper Mill compared to specified limits for organic certification.

\begin{tabular}{|c|c|c|c|}
\hline Parameter & $\begin{array}{c}\text { Primary } \\
\text { Solids }\end{array}$ & $\begin{array}{c}\text { Secondary } \\
\text { Solids }\end{array}$ & $\begin{array}{c}\text { Limits } \\
\text { organic } \\
\text { Certification }\end{array}$ \\
\hline Dry Matter $(\%)$ & 17.8 & $18^{*}$ & \\
\hline Total Carbon $(\%)$ & 37.6 & 17.0 & \\
\hline Total Nitrogen $(\%)$ & 0.5 & 0.53 & \\
\hline C/N ratio & 75 & 32 & \\
\hline pH & 7.4 & 8.5 & \\
\hline Total Phosphorus $(\mathrm{mg} / \mathrm{kg})$ & 509 & 1,203 & \\
\hline Total Sulphur $(\mathrm{mg} / \mathrm{kg})$ & 3,200 & 5,000 & \\
\hline Total Potassium $(\mathrm{mg} / \mathrm{kg})$ & 1,060 & 1,203 & \\
\hline Total Calcium $(\mathrm{mg} / \mathrm{kg})$ & 24,200 & 42,000 & \\
\hline Total Magnesium $(\mathrm{mg} / \mathrm{kg})$ & 2,440 & 863 & \\
\hline Total Sodium $(\mathrm{mg} / \mathrm{kg})$ & 1,130 & 1,582 & \\
\hline Total Boron $(\mathrm{mg} / \mathrm{kg})$ & 0.28 & 0.12 & \\
\hline Total Arsenic $(\mathrm{mg} / \mathrm{kg})$ & 1.0 & $<0.021$ & 20 \\
\hline Total Chromium $(\mathrm{mg} / \mathrm{kg})$ & 2.9 & $<0.011$ & 15 \\
\hline Total Cadmium $(\mathrm{mg} / \mathrm{kg})$ & 0.1 & $\mathrm{nt}$ & 1.0 \\
\hline Total Copper $(\mathrm{mg} / \mathrm{kg})$ & 9 & $<0.011$ & 60 \\
\hline Total Lead $(\mathrm{mg} / \mathrm{kg})$ & 1.72 & $<0.0021$ & 250 \\
\hline Total Mercury $(\mathrm{mg} / \mathrm{kg})$ & 0.04 & $\mathrm{nt}$ & 1.0 \\
\hline Total Nickel $(\mathrm{mg} / \mathrm{kg})$ & 1.3 & $<0.011$ & 60 \\
\hline Total Zinc $(\mathrm{mg} / \mathrm{kg})$ & 43 & 1.2 & 300 \\
\hline$*$ Dewatered sample taken \\
secondary solids dry matter $<4 \%$.
\end{tabular}

cultural acceptance of the technology. These trials required numerous process adjustments as the process was moved from a controlled and closed lab environment to an open-air situation.

Typically, organic wastes, pulpmill solids, municipal biosolids and kiwi fruit wastes, are received at a centralised reception area. These wastes streams are characterised, quality checked and volumes monitored prior to being blended by standard agricultural mixing technology. The blended material is then laid out in windrows directly onto the soil without any sealing or covering following the best practice standards for vermicomposting in New Zealand [21]. Width and length of the windrows depend on the site dimension but are usually $24 \mathrm{~m}$ by up to $240 \mathrm{~m}$. Compost worms are migrating into the feedstock after a maturing period of 2 to 4 weeks and start breeding immediately. Maturity of the vermicast is generally achieved after 12 months and is determined by monitoring product characteristics (analysis) or according to prescribed standards [20] (Table 2). 
Table 2: $\quad$ Characteristics of primary solids from Tasman Pulp, Paper Mill, Rotorua municipal biosolids compared to limits of New Zealand biosolids guidelines [5].

\begin{tabular}{|c|c|c|c|}
\hline Parameter & $\begin{array}{c}\text { Primary } \\
\text { Solids }\end{array}$ & $\begin{array}{c}\text { Rotorua } \\
\text { municipal } \\
\text { biosolids }\end{array}$ & $\begin{array}{c}\text { Limits NZ } \\
\text { biosolids } \\
\text { guidelines }\end{array}$ \\
\hline Dry Matter $(\%)$ & 58.9 & 14 & \\
\hline Total Carbon $(\%)$ & 34.2 & 42 & \\
\hline Total Nitrogen $(\%)$ & 0.43 & 7.6 & \\
\hline C/N ratio & 80 & 5.5 & \\
\hline pH & 7.4 & 6.1 & \\
\hline Total Phosphorus $(\mathrm{mg} / \mathrm{kg})$ & 717 & 3,700 & \\
\hline Total Sulphur $(\mathrm{mg} / \mathrm{kg})$ & 1,292 & $\mathrm{nt}$ & \\
\hline Total Potassium $(\mathrm{mg} / \mathrm{kg})$ & 2,060 & 2.210 & \\
\hline Total Calcium $(\mathrm{mg} / \mathrm{kg})$ & 78,300 & $\mathrm{nt} *$ & \\
\hline Total Magnesium $(\mathrm{mg} / \mathrm{kg})$ & 1,260 & $\mathrm{nt}$ & \\
\hline Total Sodium $(\mathrm{mg} / \mathrm{kg})$ & 2,030 & $\mathrm{nt}$ & \\
\hline Total Boron $(\mathrm{mg} / \mathrm{kg})$ & 9 & 44 & \\
\hline Total Arsenic $(\mathrm{mg} / \mathrm{kg})$ & 2.1 & 7.0 & 20 \\
\hline Total Chromium $(\mathrm{mg} / \mathrm{kg})$ & 34 & 26 & 600 \\
\hline Total Cadmium $(\mathrm{mg} / \mathrm{kg})$ & 0.16 & 0.4 & 1.0 \\
\hline Total Copper $(\mathrm{mg} / \mathrm{kg})$ & 16 & 134 & 100 \\
\hline Total Lead $(\mathrm{mg} / \mathrm{kg})$ & 4.9 & 21 & 300 \\
\hline Total Mercury $(\mathrm{mg} / \mathrm{kg})$ & 0.04 & 1.7 & 1.0 \\
\hline Total Nickel $(\mathrm{mg} / \mathrm{kg})$ & 5.5 & 14 & 60 \\
\hline Total Zinc $(\mathrm{mg} / \mathrm{kg})$ & 43 & 250 & 300 \\
\hline
\end{tabular}

*nt: not tested.

The fibrous structure of the pulpmill solids has a high water holding capacity, which allows for the operation of the worm farms without irrigation or coverage of the windrows. The height of the windrows depends on the structure of the feedstock, but should enable processing of the whole depth within 12 months without leaving anaerobic zones active within the windrow, which signifies remaining non vermicomposted organic material.

Tasman was our first commercial operation started in 2008 with approximately 2,000 tonnes of pulpmill solids and 900 tonnes of municipal biosolids per year. By 2011, this operation had grown to a total of 25,000 tonnes of combined pulpmill solids and municipal solids. This wormfarm operates on two sites with a total footprint of 17 ha and an additional 30,000 to 40,000 tonnes of material will be realised in the current year following the successful research and development that resulted in combining both primary and secondary pulpmill solids. 
Kinleith vermicomposting operation commenced with an intensive program of breeding compost worms (Eisenia foetida) in November 2008. From April 2009 primary solids were delivered to the worm farm on a regular basis. Since January 2010 all primary solids originating from the Kinleith pulp and paper mill have been vermicomposted at the MyNOKE® wormfarm since January 2010 and all secondary solids since October 2010.

In 2011 Kinleith worm farm had reached a footprint of 19.8 ha. For minimising transportation all worm farm sites are located within a $6 \mathrm{~km}$ distance to the dewatering ponds. 10.8 ha are operated on old log yard sites and a 9 ha block is located on a nearby organic certified dairy farm. Since early 2013 a 15 ha forest block has been leased for processing approximately 14,200 tonnes of municipal biosolids (Table 3) with close to 30,000 tonnes of pulpmill solids per year. First products will become available early 2014 .

The locations of the vermicomposting sites are determined where potential integration into crop or forest rotation is possible in a similar approach to studies of outdoor pig ranging in agricultural production [22]. After two to three years a rotation process results in windrows being established on new land or forestry block and the old sites are replanted with catch crops or trees after harvesting the vermicast. This way any potential enrichment of nutrients in the underlying topsoil are utilised by crop and potential hot spots for nutrient leaching are avoided.

Table 3: Pulpmill solids, municipal biosolids and other industrial wastes processed at New Zealand's central north islands vermicomposting operations in 2012 and 2013.

\begin{tabular}{|c|c|c|c|c|c|c|}
\hline \multirow[t]{2}{*}{ Organic waste } & \multicolumn{2}{|c|}{ Tasman Mill } & \multicolumn{2}{|c|}{ Kinleith Mill $^{*}$} & \multicolumn{2}{|c|}{ Maketu $^{* *}$} \\
\hline & 2012 & 2013 & 2012 & 2013 & 2012 & 2013 \\
\hline $\begin{array}{c}\text { Primary } \\
\text { pulp mill solids }(\mathrm{t})\end{array}$ & 23,346 & 16,380 & \multirow{2}{*}{38,641} & \multirow{2}{*}{43,670} & 70 & 300 \\
\hline $\begin{array}{c}\text { Secondary } \\
\text { pulp mill solids }(\mathrm{t})\end{array}$ & - & 8,396 & & & - & - \\
\hline Municipal biosolids (t) & 9,346 & 11,398 & - & 14,200 & 42 & 252 \\
\hline Kiwi fruit wastes $\left(\mathrm{m}^{3}\right)$ & - & - & 1,094 & 812 & - & - \\
\hline
\end{tabular}

${ }^{*}$ Primary and secondary solids are mixed before dewatering.

${ }^{* *}$ Maketu is a small community with a centralised wastewater treatment plant receiving pulpmill solids from Tasman Mill started in November 2012.

\section{Results and discussions}

Industrial scale vermicomposting of pulp and paper mill solids has been proven to be economically viable, environmentally safe, culturally embedded and socially accepted and supported. Crucial for the success is a bottom up approach looking from the end-user demand for a high quality product at a comparable price. Therefore, nutrient content of the vermicast should be high enough to 
achieve a contribution of plant growth while mitigating contamination issues resulting from heavy metals. This is achieved by eliminating the need for costly infrastructure and unnecessary handling, exacting quality control and monitoring and balancing the $\mathrm{C} / \mathrm{N}$ ratio to mitigate nutrient losses from vermicomposting while still producing a high quality soil conditioner.

The blended feedstock (mixed pulpmill solids) is applied to the wormfarm in windrow technology vermicomposting. The volume reduction incurred during vermicomposting is between 78 and $85 \%$. During the 2012-13 summer, a record 75 -year drought did not require irrigation of the windrows. The $\mathrm{C} / \mathrm{N}$ ratio achieved of the mixed pulpmill solids is higher than that suggested for successful vermicomposting [23]. A higher $\mathrm{C} / \mathrm{N}$ ratio of the feedstock leads to a reduction in nitrogen losses during vermicomposting, as nitrogen will remain limited for microbiological growth. The requirement for groundwater monitoring as specified under the conditions of the resource consent for our wormfarms where pulpmill solids are vermicomposted with municipal biosolids is not showing any significant increase of nitrogen concentration or metals. The vermicast produced from feedstock with a wider $\mathrm{C} / \mathrm{N}$ ratio remain with a relatively wide $\mathrm{C} / \mathrm{N}$ ratio of 29 (Table 4) and is seen as a more stable soil conditioner and therefore most favourable for most purposes such as potting mix substitute or land applied in areas sensitive to nutrient leachate [8].

Currently some 32,000 tonnes of vermicast is produced per annum from pulp and paper solids. Of this 10,000 tonnes are produced as organic certified vermicast for premium application such as kiwifruit orchards. The remainder is produced in combination with municipal biosolids (Table 5).

The application rates of vermicast vary according to purpose and demand. These can vary from approximately 2.5 to 5.0 tonnes per ha on pasture to 20 tonnes per ha to maize. For details see Table 6. On average 8.4 tonnes of vermicast are applied per ha across all sectors. In total approximately 2,740 ha of agricultural and horticultural land is currently benefitting from vermicast originating from our wormfarms in the region.

\section{Conclusion and further potentials for industrial vermicomposting}

Vermicomposting of pulp and paper mill solids in combination with organic wastes originating from food processing industries or biosolids from municipal biosolids is an economic and environmental technology to convert organic wastes into high quality soil conditioners and organic fertilisers. There is a growing demand for Vermicompost products in the primary sectors such as agriculture, forestry and horticulture. Primary industries within close vicinity of the wormfarms will derive additional benefit from reduced transportation costs. Where hog fuel or wood chips are delivered to pulp and paper mills, the backload capacities of trucks can be highly cost beneficial in the supply of Vermicompost to more remote customers. 
Table 4: Characteristics of organic certified and non-organic certified vermicast from Kinleith Pulp, Paper Mill compared to limits for organic certification and limits of New Zealand's biosolids guidelines.

\begin{tabular}{|c|c|c|c|c|}
\hline Parameter & $\begin{array}{l}\text { MyNoke } \\
\text { organic } \\
\text { certified } \\
\text { vermicast }\end{array}$ & $\begin{array}{c}\text { Not } \\
\text { organic } \\
\text { certified } \\
\text { vermicast }\end{array}$ & $\begin{array}{l}\text { Limits } \\
\text { Organic } \\
\text { Certifi- } \\
\text { cation }^{*}\end{array}$ & $\begin{array}{l}\text { Limits NZ } \\
\text { biosolids } \\
\text { guidelines } \\
* *\end{array}$ \\
\hline Dry Matter (\%) & 40-49 & 41.35 & & \\
\hline Bulk density $\left(\mathrm{kg} / \mathrm{m}^{3}\right)$ & 745 & 750 & & \\
\hline Organic matter (\%) & 33.6 & 43.6 & & \\
\hline Total Carbon (\%) & 19.5 & 25.3 & & \\
\hline Total Nitrogen (\%) & 0.65 & 1.14 & & \\
\hline $\mathrm{C} / \mathrm{N}$ ratio & 29 & 22 & & \\
\hline $\mathrm{pH}$ & 7.04 & 7.0 & & \\
\hline $\begin{array}{l}\text { Total Phosphorus } \\
(\mathrm{mg} / \mathrm{kg})\end{array}$ & 1,310 & 5,830 & & \\
\hline Total Sulphur (mg/kg) & 4,430 & 2,560 & & \\
\hline Total Potassium $(\mathrm{mg} / \mathrm{kg})$ & 804 & 1,659 & & \\
\hline Total Calcium (mg/kg) & 71,300 & 109,700 & & \\
\hline $\begin{array}{c}\text { Total Magnesium } \\
(\mathrm{mg} / \mathrm{kg})\end{array}$ & 3,420 & 1,633 & & \\
\hline Total Sodium (mg/kg) & 869 & 1,443 & & \\
\hline $\begin{array}{c}\text { Total Manganese } \\
(\mathrm{mg} / \mathrm{kg})\end{array}$ & 259 & 198 & & \\
\hline Total Boron $(\mathrm{mg} / \mathrm{kg})$ & 8 & 12 & & \\
\hline Total Arsenic (mg/kg) & 7.0 & 19 & 20 & 20 \\
\hline Total Chromium (mg/kg) & 26 & 26 & 150 & 600 \\
\hline Total Cadmium (mg/kg) & 0.50 & 0.52 & 1.0 & 1.0 \\
\hline Total Copper (mg/kg) & 53 & 48 & 60 & 100 \\
\hline Total Lead (mg/kg) & 38 & 12 & 250 & 300 \\
\hline Total Mercury (mg/kg) & 0.12 & 0.25 & 1.0 & 1.0 \\
\hline Total Nickel (mg/kg) & 14.2 & 6.0 & 60 & 60 \\
\hline Total Zinc (mg/kg) & 127 & 140 & 300 & 300 \\
\hline
\end{tabular}

* AsureQuality Organic Standard [20]; IFOAM; MPI Official Organic Assurance Programme: USDA National Organic Program; Japanese Agricultural Standard: COR - Canada Organic Regime.

** Guidelines for the safe application of biosolids to land in New Zealand [5]. 
Table 5: $\quad$ Produced volumes of vermicast at New Zealand's central north islands vermicomposting operations in 2012 and 2013.

\begin{tabular}{|c|c|c|c|c|}
\hline Vermicast/compost & \multicolumn{2}{|c|}{ Tasman Mill } & \multicolumn{2}{c|}{ Kinleith Mill } \\
\hline & 2012 & 2013 & 2012 & 2013 \\
\hline $\begin{array}{c}\text { Vermicast - not organic } \\
\text { certified (t) }\end{array}$ & 12,000 & 14,500 & - & 7,500 \\
\hline $\begin{array}{c}\text { MyNoke organic } \\
\text { certified vermicast }(\mathrm{t})\end{array}$ & & & 10,000 & 10,000 \\
\hline
\end{tabular}

Table 6: Land application rates of vermicast and areas of land application with vermicast to primary industries in 2013 .

\begin{tabular}{|c|c|c|}
\hline Primary sector & $\begin{array}{c}\text { Application rate } \\
\text { (t/ha) }\end{array}$ & $\begin{array}{c}\text { Total area of applied } \\
\text { vermicast } \\
\text { (ha/a) }\end{array}$ \\
\hline Pasture & 2.5 to 5.0 & 600 \\
\hline Cropping & 5.0 to 20.0 & 1,500 \\
\hline Kiwi fruit orchards & 5.0 & 600 \\
\hline $\begin{array}{c}\text { Others (landscaping, } \\
\text { turf, hydro-seeding, } \\
\text { domestic customers) }\end{array}$ & 5.0 to 75.0 & 40 \\
\hline $\begin{array}{c}\text { Average land } \\
\text { application rate across } \\
\text { end users }\end{array}$ & 8.4 & - \\
\hline $\begin{array}{c}\text { Total area land applied } \\
\text { with vermicast }\end{array}$ & - & 2,740 \\
\hline
\end{tabular}

Beneficial uses of vermicompost to various crops and forests on different soils have been documented widely [24-32]. Little is known on continuous application of vermicast in intensive dairying especially on pasture and intensive monoculture maize cropping systems. Intensive dairy farming is currently criticised to leading to increases in nitrate leaching and phosphate runoff, whereas intensive maize cropping may lead to a reduction in soil organic matter and therefore a carbon loss from these soils. Vermicast has the potential to increase root growth [33-35] and a regular application to farmland increases topsoil quality. As a result, vermicast has the potential to mitigate nitrate losses, increase soil organic matter directly as a carbon source and indirectly by increasing root production.

Vermicomposting of combined industrial and municipal organic wastes offers multiple positive effects on the carbon footprint for industry, the community and for the primary sectors. Of significance is the reduction in greenhouse gases emissions originating from land filling of organic wastes and the avoidance of the high economic penalties associated with the design, construction and ongoing 
monitoring of landfills. For the farming and horticulture sectors soil carbon would be increased and higher carbon sequestration by increasing root mass and crop yields. Potential fertiliser reduction would reduce the carbon footprint and a better soil structure could reduce laughing gas emissions from pastoral soils.

\section{Acknowledgements}

The author gratefully acknowledges the outstanding support from Ed Mercer and Craig Andrews from Carter Holt Harvey Kinleith Pulpmill environmental team and the wider management team for their constructive support throughout the start-up phase of the vermicomposting operation. The author would like to thank Max Morley for business mentoring to the scientific results into full-scale commercial operation.

\section{References}

[1] McGrouther, K., Wijeyekoon, S., Robinson, M., Lei, R., et al. Pulp \& Paper Solid Waste Initiative - Phase 4: Industry Strategy, 2013.

[2] Vasconcelos, E., Cabral, F. Use and environmental implications of pulp-mill sludge as an organic fertilizer. Environmental pollution 80, 159-162, 1993.

[3] Garrett, L., Wang, H. Interim report on fate and mobility of the constituents of land-applied pulpmill solid residuals. Report to Norske Skog Tasman Mill , 2006.

[4] Bostan, V., McCarthy, L. H., Liss, S. N. Assessing the impact of landapplied biosolids from a thermomechanical (TMP) pulp mill to a suite of terrestrial and aquatic bioassay organisms under laboratory conditions. Waste Management 25, 89-100, 2005.

[5] NZWWA Guidelines for the safe application of biosolids to land in New Zealand (New Zealand Water, Wastes Association, Wellington, New Zealand, 2003.

[6] Elvira, C., Goicoechea, M., Sampedro, L., Mato, S., Nogales, R. Bioconversion of solid paper-pulp mill sludge by earthworms. Bioresource Technology 57, 173-177, 1996.

[7] Elvira, C., Sampedro, L., Benitez, E., Nogales, R. Vermicomposting of sludges from paper mill and dairy industries with Eisenia andrei: a pilotscale study. Bioresource Technology 63, 205-211, 1998.

[8] Ndegwa, P. M., Thompson, S. A. Effects of C-to-N ratio on vermicomposting of biosolids. Bioresource Technology 75, 7-12, 2000.

[9] Edwards, C. A., Neuhauser, E. F. Earthworms in waste and environmental management (SPB Academic Publishing, The Hague, The Netherlands, 1988.

[10] Edwards, C. A. In Earthworms in Waste and Environmental Management (eds Edwards, C. A., Neuhauser, E. F.) 21-31 SPB Academic Publishing BV, The Hague, The Netherlands, 1988. 
[11] Arancon, N. Q., Edwards, C. A., Bierman, P., Metzger, J. D., Lucht, C. Effects of vermicomposts produced from cattle manure, food waste and paper waste on the growth and yield of peppers in the field. Pedobiologia 49, 297-306, 2005.

[12] Tucker, P. Co-composting paper mill sludge with fruit and vegetable wastes. The University of Paisley, 2005.

[13] Butt, K. R. Utilisation of solid paper-mill sludge and spent brewery yeast as a feed for soil-dwelling earthworms. Bioresource Technology 44, 105-107, 1993.

[14] Elvira, C., Sampedro, L., Domínguez, J., Mato, S. Vermicomposting of wastewater sludge from paper-pulp industry with nitrogen rich materials. Soil Biology and Biochemistry 29, 759-762, 1997.

[15] Lazcano, C., Sampedro, L., Nogales, R., Domínguez, J. Paper sludge vermicomposts as amendments into the potting media of peppers (Capsicum annium L. var longum). Compost and digestate: sustainability, benefits, impacts for the environment and for plant production. Proceedings of the international congress CODIS 2008. February 27-29, 2008, Solothurn, Switzerland 211-213, 2008.

[16] Quintern, M. Vermicomposting of lake weeds and pulp \& paper solids for carbon resource recovery for primary sectors. Report LC08/017. Sustainable Farming Fund, Ministry of Agriculture and Forestry, New Zealand, 2009.

[17] Quintern, M. Organic waste free pulpmill through vermicomposting - The Kinleith way. New Zealand Land Treatment Collective: Proceedings for the 2011 Annual Conference 32, 84-88, 2011.

[18] Quintern, M., Seaton, B., Mercer, E., Millichamp, P. Industrial scale vermicomposting of pulp and paper mill solids with municipal biosolids and DAF sludge from dairy industries. Appita 66, 290-295, 2013.

[19] Quintern, M., Wang, H., Magesan, G., Slade, A. Vermicomposting primary and secondary solids from the pulp and paper industry, 2009.

[20] AsureQuality Organic Standard For Primary Producer, 2013.

[21] NZS Composts, Soil Conditioners and Mulches New Zealand Standard, 2005.

[22] Quintern, M., Sundrum, A. Ecological risks of outdoor pig fattening in organic farming and strategies for their reduction - Results of a field experiment in the centre of Germany. Agriculture, ecosystems, environment 117, 238-250, 2006.

[23] Aira, M., Monroy, F., Domínguez, J. C to $\mathrm{N}$ ratio strongly affects population structure of Eisenia fetida in vermicomposting systems. European journal of soil biology 42, 127-131, 2006.

[24] Joshi, R., Vig, A. P., Singh, J. Vermicompost as soil supplement to enhance growth, yield and quality of Triticum aestivum L.: a field study. International Journal Of Recycling of Organic Waste in Agriculture 2, 16, 2013. 
[25] Hidalgo, P. Agricultural, M. Earthworm castings increase germination rate and seedling development of cucumber. Office of Agricultural Communications, Mississippi State Unniversity, 1999.

[26] Lazcano, C., Sampedro, L., Zas, R., Domínguez, J. Enhancement of pine (Pinus pinaster) seed germination by vermicompost and the role of plant genotype. Compost and digestate: sustainability, benefits, impacts for the environment and for plant production 253-254, 2008.

[27] Lazcano, C., Revilla, P., Malvar, R. A., Domínguez, J. Yield and fruit quality of four sweet corn hybrids (Zea mays) under conventional and integrated fertilization with vermicompost. J Sci Food Agric 91, 1244-1253, 2011.

[28] Lazcano, C., Sampedro, L., Zas, R., Domínguez, J. Vermicompost enhances germination of the maritime pine (Pinus pinaster Ait.). New Forests 39, 387-400, 2010.

[29] Arancon, N. Q., Edwards, C. A., Lee, S., Byrne, R. Effects of humic acids from vermicomposts on plant growth. Eur. J. Soil Biol 42, 65-69, 2006.

[30] Arancon, N. Q., Edwards, C. A., Bierman, P., Welch, C., Metzger, J. D. Influences of vermicomposts on field strawberries: 1 . Effects on growth and yields. Bioresource Technology 93, 145-153, 2004.

[31] Atiyeh, R. M., Lee, S., Edwards, C. A., Arancon, N. Q., Metzger, J. D. The influence of humic acids derived from earthworm-processed organic wastes on plant growth. Bioresource Technology 84, 7-14, 2002.

[32] Arancon, N. Q., Edwards, C. A. Effects of vermicomposts on plant growth. Proceedings of the Vermi-Technologies Symposium for Developing Countries, Department of Science and Technology. Philippine Council for Aquatic and Marine Research and Development, Los Banos, Philippines, 2006.

[33] Canellas, L. P., Piccolo, A., Dobbss, L. B., Spaccini, R., et al. Chemical composition and bioactivity properties of size-fractions separated from a vermicompost humic acid. Chemosphere 78, 457-466, 2010.

[34] Zandonadi, D. B., Canellas, L. P., Façanha, A. R. Indolacetic and humic acids induce lateral root development through a concerted plasmalemma and tonoplast $\mathrm{H}+$ pumps activation. Planta 225, 1583-1595, 2007.

[35] Canellas, L. P., Teixeira Junior, L. R. L., Dobbss, L. B., Silva, C. A., et al. Humic acids crossinteractions with root and organic acids. Annals of Applied Biology 153, 157-166, 2008. 